\title{
THE PROTECTION OF THE FAMILY
}

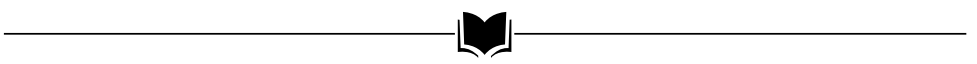

BARNABÁS LENKOVICS

\section{Extent and delimitation of the topic}

One of the joint research topics of the Eastern European Professors' Network is the "Protection of the Family in Law." The designation of this research topic can already be regarded as a delimitation in itself, since it refers only to the grounds and optimal means of legal protection. However, if we omit this restriction on the law (when discussing "Protection of the Family"), it immediately becomes apparent how much broader the research topic is. The protection of the family dates back to the beginning of human evolution (to prehistoric times), and its toolbox originates in the natural laws that long preceded the establishment of the state and the law. In addition to law, this broad field of research can also be explored via many other disciplines (biology and ethology, generally speaking, but especially human ethology, psychology, sociology, anthropology, and cultural anthropology). Among them, we can find not only social sciences but also natural sciences. All of these are sub-fields of "science," and their common denominator is that their subject is mankind, i.e., they are the human sciences. In its ultimate essence, "the goal of the acquisition of all human knowledge is the better self-knowledge of the man." It is, therefore, expedient and useful if these research results are utilized by jurisprudence. In this sense, I try to broaden the thinking base of jurisprudence in this complex topic and to "socialscientificize," or more generally to "scientificize" the jurisprudence, in order to avoid

1 Lorenz, 1988, p. 93.

Barnabás Lenkovics (2021) The Protection of the Family. In: Tímea Barzó, Barnabás Lenkovics (eds.) Family Protection From a Legal Perspective, pp. 9-36. Budapest-Miskolc, Ferenc Mádl Institute of Comparative Law-Central European Academic Publishing. 
the accusation of "one-track thinking." 2 This is a difficult field and an unusual methodological experiment, owing to its diversified complexity. For example, "ethology analyzes human behavior as a subject of the functioning of a particular system. ... The analysis of the organic system that is the basis of human social behavior is the most difficult and at the same time the boldest task, because this system is far the most complex on Earth'. ${ }^{3}$ However, the leading examples of bio-economics (in the harmonization of natural laws and economic principles) and behavioral economics (in the harmonization of the material and intangible, spiritual needs of man) prove that it is not impossible to accomplish the task. Man is a natural and social creature, living in these two systems, in their subsystems, and in their reciprocal interactions. As such, people marry and start a family, causing natural and social crises, including physical and mental crises that are both internal (self-conflicts) and external (one's marriage partner and family), for the purpose of creating future generations.

After these introductory remarks, it can be stated that the protection of the family is one of the oldest natural and moral laws, the extension of legitimate self-defense of descendants to the co-genitor, to the wider family and relatives, and even to the entire human community formed by families (regardless of the size of these communities and what we name them: genus, tribe, tribal alliance, people, nation, etc.). Self-defense, offspring protection, family protection, and community protection are all manifestations of the survival instinct in the biological sense. Based on this, humans-like all other living organisms in general—must survive and, being mortal, reproduce the inherited genes so that their parent's essence can continue in the lives of their descendants and their offspring's descendants (and so on). That is the reason a person establishes a heterosexual relationship, starts a family, tries to create security for it, and protects one's family even at the cost of the life of the attacker, and, in extreme cases, at the cost of his/her own life. In comparison, it is a bagatelle sacrifice if a person has to limit his/her own hedonism for self-defense. If family protection as self-defense is successful and families survive, then not only are parents' genes reproduced but also wider communities and society are preserved. "While it may seem foolish to emphasize something that is so obvious, social capital cannot exist without people, and Western societies simply do not create enough people to sustain themselves." ${ }^{4}$ Therefore, if necessary, the whole community must protect every single member and every family, since these are the constituent parts and the basic and natural units of the community. All of this is really quite natural (in the language of the law: evident) to the extent that we should not even have to question it. This would be true if marriage and family worked hand-in-hand with this natural law. However, it appears that modern marriage and the family are no longer working as they once did; indeed, such institutions are in crisis in Europe and wider Western civilization. Europe, as a continent and a civilization, is the only one in which the 
overall population is declining and aging. ${ }^{5}$ For more than half a century, willingness to marry has been on the decline, a large proportion of marriages have fallen apart, couples have not had children, have been unable to have children, or have had fewer children than planned. Generally speaking, selfishness and violence have been ruining families. As a result of the population decline, white people (belonging to Western or European Christian culture) are in danger of extinction in the foreseeable future. (Meanwhile, man puts plant and animal species at the same risk under increased protection!) The self-defense reflexes of marriage and family do not work or are insufficient. The collapse of marriage and the family-in addition to crime and loss of trust-is one of the main causes of the "Great Disintegration." ${ }^{\prime \prime}$ Conscious and voluntary intervention is therefore needed to protect social reproduction, marriage, and the family as a dual effort of both the law and society. However, since law is-in its ultimate essence-a human rule of conduct that is accompanied by the external coercive public power of the state, this intervention also raises a number of difficult questions. When, for which reasons, for which purposes, and by which means must there be interventions? This study attempts to contribute to solving the crisis of marriage and the family via methodical approach. For the correct answers, we need to identify the root causes of the crisis with scientific rigor, elucidate the goals to be accomplished by tackling the crisis, and select the most appropriate and sufficient legal instruments to achieve them. In addition, we must not forget that we have internal controlling norms (natural and moral laws), and it is good that they pull in the direction of resolving the crisis.

\section{Human and legal starting point}

The starting point of legal research cannot be other than man, since we research the crisis of the two natural and indispensable institutions of human existence, marriage and the family, which we wish to protect by means of law, for the sake of man. It is true here as well-which I have claimed for a long time-that the law is for humans, and not the humans for law. Therefore, we must talk about the first part of the highest legal definitions_-"rights of humans," "human rights," "human dignity," i.e., about humans themselves. Philosophers generally agree that humans have emerged from the animal kingdom as the "crown of creation," either as a creature of God or as a result of evolutionary development. The views of other living creatures are not yet known on this issue, although the views of native species already extinct by humans as invasive species in particular could be very remarkable. That said, while it seems likely that humanity as whole will survive for the foreseeable future,

5 Gallai, 2019, p. 16.

6 Fukuyama, 2000, pp. 59-72. 
there are some groups of people at risk of extinction. From the point of view of the destruction of the natural foundations of life on Earth by humans, the danger of a climate catastrophe resulting in our eventual extinction has reached the overpopulated human species nowadays. Overpopulation is discussed by Konrad Lorenz as the first of the eight deadly sins of civilized humanity because it is also the cause of several other catastrophic dangers (destruction of living space, frostbite of emotions, and genetic decline). ${ }^{7}$ The population explosion, therefore, has also diverted attention for some time from the other extremity, depopulation. I mention this mainly to show that it is not enough to deal with the crisis of marriage and family of certain groups of people and to protect and support these institutions legally; it also needs to be known that human life is threatened by other, even more serious dangers that need to be urgently and effectively addressed. Second, I mention it because I think that the institutions of marriage and family are also part of the natural foundations of human life. Although they became a part of the system of legal regulation (the legal system) and therefore became legal institutions and social institutions, they did not cease to be a natural phenomenon, a natural principle, and they could not be intentionally torn from their natural foundations without their destruction. As humans are primarily natural (biological, biophysical, biochemical, psychosomatic, etc.) beings, they are subject to the laws of nature as such. The majority of our most serious human problems (such as the danger of a climate catastrophe) stem precisely from the fact that man has been too far removed from nature, torn from it, and even confronted with it, to the point that he now imagines himself not as part of nature but as its master. "The general and rapid alienation from living nature is largely responsible for the aesthetic and moral roughness of civilized man." ${ }^{8}$ Man is already playing "god" ("Homo Deus," as YN Harari calls him in one of his books), wanting to force his own human laws on nature instead of adapting (as other living beings) to the laws of nature (see: evolution). As one of the contemporary human aspirations, this distorted phenomenon also affects the institutions of marriage and the family and some people want to "re-create" these as well. This is not surprising because "man" is an extremely complex, intricate creature. According to the evolutionary biologist and historian couple, Kai Michel and Carel van Schaik, man has three natures. The first is our "natural nature."

The first nature embraces our innate feelings, reactions, and preferences. These have evolved over hundreds of thousands of years and have proven their effectiveness in the daily lives of small numbers of hunter-gatherer groups. (...) Inclinations such as love between parents and their children, a sense of justice, outrage over injustice and inequality, and a sense of duty to others after accepting a gift or help belong to this first nature. ${ }^{9}$ 
The second nature is our "cultural nature," which includes the components of propriety, politeness and good manners, morals and customs, the arts and religions, and "civilization" in the broadest sense. The third nature centers on our "rational nature." It includes the basic rules, practices, and institutions to which we conform consciously, relying on our intellect. ${ }^{10}$ The three natures of man act simultaneously, partially overlapping with each other; their effect is optimal and positive when combined, but they can sometimes be confused with each other. An example of the interaction and overlap between these natures is the rule of family law (third nature), according to which providing support for minor children takes precedence over the parent's own needs. Aside from legal implications, certain actions related to the family are also required by morality (second nature), and are the command of nature (first nature). Due to such overlap, conflict may arise if, in the same way as marriage between a man and a woman (first nature), people of the same sex can marry (third nature) with the permission of the law. In the latter case, the second nature (morality and culture) can shift toward the first or third nature. Our premise regarding the legal regulation and protection of marriage and family is that none of the parts of human nature can be ignored or overemphasized. Therefore, neither the legal regulation (third nature), which is closed to itself, nor the first nature is free from internal contradictions and seems very rational.

A similar explanation expressing the complex and intricate nature of man can be found in the bioethical-psychologist József Kovács. According to him, man is a "biopsychosocial" being as a result of his combined physical (somatic, genetic), spiritual (mental), and communal (social, social) talents. "Evolutionary psychology and psychopathology assume that human beings are not only a somatic but also a mental product of Darwinian natural selection: our mental characteristics essentially served for the adaptation in the ancient environment in which $99 \%$ of human evolution took place." Regarding modern life, Kovács stated that we live in

a completely different environment than the one to which we have adapted, which means that we are not mentally ill, but our modern environment is not created in accordance with the psychological needs of man. (...) Man (...) is maladapted to his current environment. We could also say that man has domesticated himself and lives in a kind of self-created zoo, which is comfortable and safe compared to the ancient environment, but it does not enable the complete behavioural repertoire of the species under its natural conditions, and therefore neither psychic satisfaction nor happiness under natural conditions. ${ }^{11}$

Maybe that is the reason why more and more people desire to return to nature. Could it be that as this is their native environment they feel truly happy there? Perhaps this is the reason why the so-called "happiness index," which valorizes 
natural values (e.g., clean air and drinking water, healthy soil and food, peace and quiet, marriage and family, kinship, and friendships) has recently been calculated in addition to/instead of GDP indicators. "Scientists have only just begun to research the history of happiness in the past few years, and we are still developing the initial hypotheses and looking for the right research methods. (...) I think this is the biggest white spot in the assessment of our history. We should start to fill it out". ${ }^{12}$ Thus, there is some evidence that a harmonious marriage, a peaceful and safe family environment, provides the greatest happiness for both parents and children. ${ }^{13}$ However, both institutions are in crisis, and their protection and support are needed. Even though people now have many rights ("human rights"), they do not seem to be happier as a result. On the contrary, they tend to lose confidence in the law. Although it is not certain whether the fault is in the law the decline in public confidence in legal institutions should be stopped and general faith it their efficacy restored. Let us begin by taking a closer look at the universal human rights standards that serve as the starting point for our research, i.e., the legal protection of the family. These are set out in the United Nations 1948 "Universal Declaration of Human Rights" (hereinafter, UDHR). It should be noted that while the 1789 French "Declaration of the Rights of Man and of the Citizen," which served as the model for the UDHR, declared that "men are born and remain free and equal in rights" (Article I), "the law must be the same for all," and "all citizens are equal in its eyes" (Article VI), it did not specifically mention the equality of men and women, including the equality of spouses, nor did it comment on marriage or the family. However, these general declarations were suitable for the organization of the women's emancipation movements to liberate women from male domination and to achieve equal rights for women (e.g., equal access to universities, entry into professions, state-public participation, voting rights, etc.). The struggle of the labor movements against the rule of capital for higher wages, social security, and social (material) equality also expanded protections of workers' families, especially children of employees and the emancipation of working women. The results of these struggles-more than two centuries later-are already reflected in the text of the UDHR (in which the former bipolar world system also played a role).

According to point 5 of the Preamble of the UDHR, "the peoples of the United Nations have in the Charter reaffirmed their faith in fundamental human rights, in the dignity and worth of the human person and in the equal rights of men and women and have determined to promote social progress and better standards of life in larger freedom." This is also mentioned in Article 22 of the UDHR, although in a general way:

Everyone, as a member of society, has the right to social security and is entitled to realization, through national effort and international co-operation and in accordance 
with the organization and resources of each State, of the economic, social, and cultural rights indispensable for his dignity and the free development of his personality.

Such rights will be further enumerated by the United Nations International Covenant on Economic, Social, and Cultural Rights of 1966. The text speaks of individuals as members of society, but the fact is that the vast majority of people live in a family (especially children), and the right to social security is typically related to the family. In this sense, we have to mention Article 23(3): "Everyone who works has the right to just and favourable remuneration ensuring for himself and his family an existence worthy of human dignity, and supplemented, if necessary, by other means of social protection." Here I also would like to mention that this idea has already appeared in Rerum Novarum, the encyclic of Pope Leo XIII of 1891:

A worker, if he lives reasonably, and if his salary is sufficient to support himself, his wife, and his children decently, will spare money and attain what nature itself urges him to keep, in addition to the necessary expenditures, something from which he can make a modest fortune over time. ${ }^{14}$

However, it is well known that wages have always been adapted to the principles of the labor market rather than to the circumstances of the worker's family (number of children, housing conditions, degree of poverty). That is the reason it has become necessary to link employment with the ever-expanding toolbox of "social legislation," social protection (health and pension insurance, family allowances, free public education, maternity and childcare allowances, social benefits, etc.). These are regulated in Article 25(1)-(2):

Everyone has the right to a standard of living adequate for the health and well-being of himself and of his family, including food, clothing, housing and medical care and necessary social services, and the right to security in the event of unemployment, sickness, disability, widowhood, old age, or other lack of livelihood in circumstances beyond his control. Motherhood and childhood are entitled to special care and assistance. All children, whether born in or out of wedlock, shall enjoy the same social protection.

With this background regulation, especially if these rules prevail in practical life, it is already possible and worthwhile to get married, start a family, and have a child (children). This makes the three paragraphs of Article 16 of the UDHR, which is most closely related to our subject, more comprehensible and interpretable: 
(1) Men and women of full age, without any limitation due to race, nationality, or religion, have the right to marry and to found a family. They are entitled to equal rights as to marriage, during marriage and at its dissolution.

(2) Marriage shall be entered into only with the free and full consent of the intending spouses.

(3) The family is the natural and fundamental group unit of society and is entitled to protection by society and the State.

It is obvious from these norms that marriage and the family are global (universal) fundamental human rights values; marriage, the choice of partner and the foundation of family (having children) have risen to the rank of fundamental freedoms. In addition, in accordance with the first nature of man, self-evident basic truths and natural laws can be read from them: marriage and, in the same way, the foundation of family requires a man and a woman; the spouses are equal parties; the family as a "small" community is a "natural" and "essential" component—or "cell," according to the well-known synonym - of society as a "large" community. If this cell becomes ill or dies, so does the society. Therefore, if necessary, we must protect health and integrity; to cure and rehabilitate if it has symptoms of illness (crisis). Protection is primarily a social matter, but should it prove insufficient the state is also obliged to protect the family, by using public means, rewards, subsidies, or prohibitions.

Many people regard the Universal Declaration of Human Rights and the whole expanded system of fundamental freedoms and human rights as the Magna Carta of mankind; the peak of the development of human civilization. Others consider this system of fundamental rights and legal values as a universal (universal, global) constitution of . It is important-as the $3^{\text {rd }}$ declaration states-that "human rights should be protected by the rule of law." Therefore, "Member States have pledged themselves to achieve (...) the promotion of universal respect for and observance of human rights and fundamental freedoms" ( $6^{\text {th }}$ declaration) and "strive by teaching and education to promote respect for these rights and freedoms and by progressive measures, national and international, to secure their universal and effective recognition and observance, both among the peoples of Member States themselves and among the peoples of territories under their jurisdiction" ( $8^{\text {th }}$ declaration). Considering this, the sole question is why such an almost perfect system does not work as intended-why do struggles such as marriages and families with symptoms of crisis persist? This is neither the first nor the only case in which there is a large discrepancy between the solution considered legally ideal and the social reality. Thus, the goal is precisely to bring the reality-in which there is always room for improvement-and the ideal. The real problem is when reality moves in a direction different from the objective or when it moves away from it instead of approaching it. This is a problem with marriage and the family as well: they seem to develop in other directions (alternative forms of relationships, same-sex marriage), but their stability and reproductive function deteriorate. The causes can be found in the law itself (in its unrealistic or irrational expectations), in the natural and socio-economic-cultural 
environment that determines the law (which is constantly changing while the law is often static and rigid), and of course in the person him or herself, who is both a natural and a social being. Man is not yet perfect in his humanity; therefore, his constructed rules and expectations are likewise imperfect. However, a ray of hope in a crucial world is to see the fundamental human rights values of the universal constitution of humanity as milestones, compasses, and right alignment points that show the proper direction and bring us closer to ideal solutions. Compared to these, we can measure crises, look for their causes, and find the means of solving them.

\section{The historical roots of the crisis of marriage and the family}

I intentionally do not talk about the "beginning" of the crisis of marriage and family, since it cannot be determined by scientific precision, partly because we do not even know from what point in history we can talk about marriage between a man and a woman. "Man has been living for 2.5 million years from collecting plants and hunting animals that lived and reproduced without his intervention." 15 We do not have any factual information about this prehistoric time. However, scientific assumptions are permissible. "For hunter-gatherers, the relationship between men and women was pretty much still balanced. Although the man dominated to some degree, if the woman was dissatisfied with her husband's abuse of power she could return to her family at any time or change husbands. The bondage to the partner was not necessarily exclusive. Although there were monogamous relationships, it was not a common practice for a woman to be bound to a man for her entire life. A woman could have different partners; one after the other or even at the same time. Such promiscuity did not meet obstacles because paternity could not be established. Contact with more men served the interests of the woman since a network of potential fathers could be built in this way, all of whom felt responsible for their partner. ${ }^{16}$ Of course, it has to be added that they felt responsible for all children in the community. "All of this changed about 10,000 years ago, when homo sapiens began to devote almost all of his time and energy to manipulating the lives of some animal and plant species. (...) It was a revolution in the human way of life-the agricultural revolution."17

The Neolithic revolution broke with one of the fundamental laws of human coexistence that has prevailed in the everyday life for many thousands of years-with the rule that food must be shared. The new idea of property undermined the solidarity of 
prehistoric man. Everything which had been a common good until then-food provided by nature-had become monopolized at one blow. That was the real scandal! It is not enough that a daily, vital activity—the collection of fruit—will be banned; it will even be treated as a crime. We still feel the aftermath of this scandal. ${ }^{18}$

This, perhaps the greatest paradigm shift in the history of mankind, has also transformed man himself, his family, and society as a whole. The selection, domestication, and production of animal and plant species made man greatly independent from the whims of nature; it enabled him to stand on his own two feet through his own work. Until then, nature had dominated man and we had had to invest in social relationships-mutual help, cooperation, and solidarity had worked as a kind of life insurance. Nowadays, "people are no longer so interdependent; they can better neglect their social relationships. The path they stated to move on was a oneway street, which led to a world that was getting richer financially but becoming increasingly poorer socially and emotionally." As community relationships faded, family relationships became more valuable and tighter. In addition to passing on life, men also had to inherit private property. The boys stayed to work the farms with their fathers within the family unit. They had to find and bring a woman to the house from the outside, and these girls were endowed. "In the forming of the patriarchate, women become commercial goods and property. (...) The first victims of the shift were women." ${ }^{19}$ At the same time, "where reserve management is successful, the population jumps. Competition is becoming dominant and social disparities are growing. Hierarchies and forms of dominance evolve." 20 This is also true for marriage and family relationships. The wife comes under the power of her husband, the children come under paternal power, and their liberation-if at all-will be the result of struggles of many centuries and even millennia. I will mention just one example of this:

The patriarchal world is raising female fidelity to the rank of a norm. (...) When women become male property, their power must be regained. However, this power is mainly based on sexual attraction. (...) After being expelled from Paradise, Eve must get dressed to hide her charms under a dress. ... In farming societies, it is mainly women who have to dress morally. ${ }^{21}$

Nowadays, its "aftermath" is the debate over the dress of immigrant Muslim women in many Western European countries. According to this (according to the evolutionary reading of the Bible), original sin was nothing more than the agricultural revolution, the consumption of the forbidden fruit of the tree of knowledge, the 
punishment of which is the expulsion from the Garden of Eden, the natural form of life. The three main consequences are

the issue of torturous labour, the difficulty of accepting property, and finally the embarrassing fact of the subordination of women-three burning problems which humans have struggled with since we transitioned to a settled lifestyle. In this respect, the situation has not changed much in the last ten thousand years. ${ }^{22}$

Another important circumstance-from the point of view of its current, daily relevance, and of our topic-has to be mentioned.

The measure of the evolutionary success of a species is also the number of copies of its DNA. If no more copies of DNA remain, the species will become extinct. (...) If a species makes a lot of copies of DNA, it is a success and the species thrives. This is the essence of the agricultural revolution: the ability to survive even in worse conditions. At the same time, it is a trap because the growth of the population has burned the bridges behind humanity. (...) There is no return. The trap is closed. ${ }^{23}$

Clearly, there is no return to the Garden of Eden. However, the mitigation and remedy of the negative effects of property are not hopeless. One of these negatives is the extension of one's "ownership spirit" to

friends, to the love partner, to health, travel, artefacts, God, and to one's own self. (...) The greatest pleasure lies perhaps not in the control of material things, but in the control of living entities. In a patriarchal society, even the poorest man himself owned his wife, children, and possessions, and he could imagine himself to be their absolute master. It is definitely true of this type of society that a great number of offspring is the only way to own people without being forced to work or invest capital to do so. Considering that the burden of this must be borne by the woman, it can hardly be denied that raising offspring is a process of gross exploitation of women. However, the mother has also a kind of property: her child when he/she is still small. It is a vicious circle: men exploit their wives, women exploit their children, growing men join their fathers and exploit women. The male rule in the patriarchal system lasted for about six to seven millennia, and even if it began to disintegrate, it did not disappear, especially in poor countries and the lower classes of society. ${ }^{24}$

In conclusion, we wanted to illustrate that the origins of the crisis of marriage essentially coincide with the emergence of monogamous marriage in today's sense, which was a consequence of the development of private property, agriculture, 
settlement, and patriarchal society. However, the fault did not and does not lie in monogamy. It is quite the contrary! "Societies that are based on stable families, monogamy, loyalty, and responsibility can mostly expand and prosper. Societies that are sexually more permissive, that accept short relationships, easy divorce and family relationships are more unstable and doomed to decline." ${ }^{25}$ Man, his mode of existence based on possession and his desire for domination over other people is the real problem, which is still the ruin of countless marriages. Therefore, we briefly review the changes in the ownership-economic order and the related characteristics of marriage and family related to historical ages. After that, we will turn to the crisis symptoms of the $20^{\text {th }}$ century, their causes and tendencies, and crisis management by the state.

\section{Schematic images of marriage and family}

"Bella gerant alii, tu felix Austria nube!" Let others go to war, you get married, and happy Austria! This motto of Habsburg House, aimed at the construction and survival of the empire, is part of history education in Hungary and in the successor states of the Habsburg Empire. Its principals have also been practiced in other European royal houses as the Hungarian kings married their daughters to the royal families of other countries while their sons married the daughters of foreign sovereigns. We can say that the royal houses of Europe formed a large, common family. "Blood kinship"-as in prehistoric times-meant a strong bond and, although it did not completely rule out it reduced the chances of war. However, the main function of royal marriages was the acquisition and/or maintenance of the status of the monarch, including the inherent power and the dominion over territories and people. This attitude pervaded the entire vertical feudal hierarchy. It was forbidden to marry "below one's rank" or it was allowed only with the prior permission of the overlord. This guaranteed the preservation of the given status and the associated birth privileges at all stages of the hierarchy, and therefore the maintenance of the feudal social order as a whole. This also resulted in it being almost impossible for the serfs to change of their status, at least through marriage. The system also involved the church since the institution of "holy marriage" was governed by ecclesiastical law. What God bound together man could not dissolve (it could only be invalidated by the church with a very complicated and cumbersome procedure). The practice of marriages of the appropriate order and rank, aligned with the hierarchy of power and wealth, was deeply ingrained in European culture, although there was no caste system there. Although feudal birthrights were replaced by the inherited privileges of great wealth ("lords of fortresses" are "lords of factories"), it was not suitable to marry "below 
one's rank" in capitalism either. "Capital married with capital" and "factory married with factory," and even "land married with land" in connection with peasants, which aimed at preserving and strengthening the property status occupied in the order of ownership and economy. ${ }^{26}$ The late embourgeoisement was the specialty of the Hungarian "feudal capitalism" - the impoverished nobleman (gentry) married the daughter of the rich manufacturer, or the rich manufacturer (in a less hazardous way) first bought a "baronial rank" and then married according to his rank. It was exceptional-as in the tale of the prince with the snow white horse-that the bank manager came with a "fairy tale car' to ask for the hand of the poor typewriter. The mutually reinforcing institutions of civil society, civil property, and civil marriage had already been harshly criticized and considered to be liquidated by Marx and Engels in the Communist Manifesto:

What is the basis of the current, civil family? Capital, private acquisition. In its fully developed form, this family exists only for the bourgeoisie, but its supplements are the forced familylessness of the proletariat and public prostitution. The bourgeois family naturally ceases with the cessation of this supplement, and both disappear with the disappearance of capital. ${ }^{27}$

However, what replaces the family with a change in the means of production into social property?

Wage labour and the proletariat is also disappearing. Prostitution is disappearing and monogamy, instead of disappearing, will finally become a reality - for men too. In any case, the situation of men is changing a lot. But the situation of women, the situation of every woman is also going through a significant change. With the public ownership of the means of production, the monogamous family is no longer an economic unit of society. Private households are transforming into social activities. The care and education of children are becoming a public affair. ${ }^{28}$

Since the means of production did not become the property of the society but of the state, the workers became "wage slaves of the state" instead of the wage slaves of capital. Neither wage labor nor the proletariat has disappeared. Moreover, a mass of women became wage workers in order to ensure a "two wage earners" family model for a mere subsistence. On the other hand, the monogamous family was no longer an economic unit of society. However, if it could have remained, it would have been able to perform miracles, just as in Western European countries. The incessant pursuit of people to create a greater degree of livelihood security and well-being for themselves, their families, their children, and their grandchildren is an incredibly 
powerful impetus that results in rapid and wide socio-economic development. Socialism turned off this driving force, as it limited the material scope and extent of personal (consumer) property. While it hypocritically proclaimed that "the greatest value in socialism is man," in Hungary, "unusual" socialism was built. In 1968, it introduced a "new economic mechanism" (regulated market economy) and allowed the "backyard" family farms in agriculture, which was extended to industry and services in 1982. This system was nicknamed "Fridge Socialism" and "Goulash Communism" by the Orthodox Communists. This was the last impulse of the right to private autonomy, of private law, whose-according to Károly Szladits- "main subjects are private economy and family life; private law is essentially property law and family law." ${ }^{29}$ The family and the family economy (today micro, small, and medium-sized enterprises) are the main arenas for the socialization of future generations: they educate the populace in the matters of work, cooperation, mutual support, solidarity, and even selfless love. All of these are socially useful fundamental values beyond the law. This was destroyed by the totalitarian state of the proletarian dictatorship with tectonic destruction. The conscious transformation of social-economic-property relations resulted in (to put it mildly) large-scale "social mobility," which tore apart the ties of marriage, family, relatives, village community, civil society, and the "social safety net" that are so highly valued today. In lieu of self-care, state paternalism was introduced, whereby whoever is cared for by the state does not require family care. This kind of great collectivism, however, has strengthened egocentric selfishness, which loosens the bond of marriage and disintegrates the family. It is a historical rarity that marriage and the family have been equally affected in parallel to the development of industrial society coupled with the growth of capitalism from free-competitive wild capitalism to the more structured social market economy and welfare state. In the economic struggle of the bipolar world system, the socialist states, as "communal" (ideological) capital owners, ${ }^{30}$ fought with capitalist big capital and its liberal states, but their common essence was that both needed a mass of "free" (i.e., freely exploitable) wage workers-proletarians. Therefore, both expelled peasants from their lands; assaulted large numbers of weaker citizens, family farmers, and small entrepreneurs; moved to industrial cities; and crowded the masses of wage workers into rental housing. It is not a coincidence that these were referred to as "wage barracks," while their inhabitants were called "industrial armies" and "wage slaves" because of their low wages. Konrad Lorenz wrote about "farms of human livestock" saying:

The caged chicken factory can rightly be regarded as animal torture and a cultural scandal. However, it is considered perfectly acceptable to do similar things with humans, even though these are the humans who cannot tolerate such inhumane treatment in the truest sense of the word. As a result of the human evolution, man 
could not bear to be one of millions of individuals who are completely similar, anonymous, and interchangeable. Only one way remains to maintain the self-respect of the inhabitant of the farms of human livestock, namely, to banish the similar companions of his suffering from his consciousness, and to rigidly distance himself from them. ${ }^{31}$

As a consolation-and to cover up material poverty-the equality of all people, the freedom of individual self-determination, the dignity of the individual, and the abundance of human rights were increasingly stressed on both poles of the world system. However ,the shift of emphasis was "too good": although it may be an unintended outcome, it has also assaulted the relationship, the small communities, and marriage and the family that functioned as a major source of happiness for the individual. ${ }^{32 "}$

It is clearly seen that the fragmentation of families leads to a serious demographic and health situation, to the disappearance of the social safety net and to the threat of the very existence of the society. Nowadays, those who work to protect the institution of the family do the greatest service to humanity and protect the truth. ${ }^{33}$

\section{Individual selfishness and the world of selfishness}

The essence of scientific thinking is to try to condense reality into concepts. This is especially true in the social sciences (philosophy, ethics, sociology, economics, and law). If the concept and the reality are the same, the concept is true; if they are different, the concept is false. Moreover, the ever-changing reality may later deviate from the originally true concept, which could, therefore, become false. In this case, the (legal) concept must be adapted to the changed reality to ensure that the concept remains true. However, law has a very important feature: nowadays, the only source of law is the State as a public power. Therefore, the law itself is a power: a set of coercive rules prevailing in the State. It is suitable to align reality with its own concepts, thereby preserving its "truth." This shaping of reality can take two forms: it prevents reality from changing in the wrong direction or it hinders the change in the right direction. Later, we will apply these ideas to the concepts of marriage and family, but first we will analyze the key concept that mostly covers the reality of our modern world, which is individual freedom. If we use synonyms instead of the indicated concept (i.e., the noun "freedom" the difference between the concept and 
the reality immediately emerges: individual selfishness. Here, the root of the tension between the two also lies in the concept of private property, which decisively determines the entire economic and social order. Private property is a self-contradictory, Janus-faced concept (a legal institution and a socio-economic institution): on the one hand, it has the effect of increasing wealth, developing personality, and increasing individual freedom, while on the other hand, it provides a sole and exclusive legal power over the subjects of property and-through them-over other people, thereby reducing and/or violating the individual freedom of others. This duality began with farming and early human settlements, which exploded after, the "agricultural revolution." It continued and was strengthened by the Industrial Revolution, and has become extreme in our contemporary world of global capital and a global market. It is not a wonder, since all people long for freedom, that we see a desire for wealth, and then power, neither of which have an upper limit. The ethnicization and socialization of law, i.e., the education of capital for social responsibility, tries to limit the pursuit of domination, but has had only moderate success thus far. In particular, there are the so-called "first-generation human rights"- the fundamental freedoms belonging mostly to individuals, both as human beings and as citizens. The preamble to the Charter of Fundamental Rights of the European Union also states that the Union "places the individual at the heart of its activities." However, the value of each individual can vary dramatically and it can deviate significantly among cultures and civilizations.

The concept of personal me used in India and Japan is sociocentric. It is less individualized, much more family oriented ... than protestant personal me in Northern Europe, which is much more egocentric (emphasis added by me: B.L.). From the point of view of the Eastern sociocentric concept of personal me, the Western, egocentric concept of personal me is alienated, antisocial, and naive. However, from the point of view of the Western, egocentric concept of personal me, the Eastern, sociocentric concept of personal me is not individualized, undeveloped, too dependent on others and immature ${ }^{34}$

It is obvious which concept is more useful for the family as a community, but it can be questionable as to which is more economically efficient. Ernst Schumacher, an eco-economist, quotes the opinion of Keynes (from 1930):

For at least another hundred years, we have to convince ourselves and everyone that the good is evil and the evil is good because evil is useful while good is not. Let greed, usury, and suspicion be our gods for some time, because only they can lead us out of the tunnel of economic need into the light. ${ }^{35}$ 
Envy, greed, unscrupulous selfishness, and dishonesty can undoubtedly bring great financial advantage and economic development in the short term. However, if-in the longer term and in other contexts-egocentric, individual selfishness disrupts marriage and family, tears apart the network of social trust, and-as we see nowadays-pushes the entire "Western" civilization to the brink of demographic collapse, then the balance tilts towards harm.

However, people soon realized that there were serious problems with a culture of unbridled individualism in which, in some sense, breaking the rules remained the only rule. (...) A society that resolutely and consistently destroys norms and rules in the name of enhancing individual freedom will become increasingly disorganized, atomized, and isolated, and will be unable to achieve common goals, perform common tasks. ${ }^{36}$

According to the brain researcher Tamás Freund, it is a biological truth that trust, reciprocity, and cooperation remain the basis of social existence. Selfishness, on the other hand, is an evolutionary impasse, and selfish individuals and species are doomed to extinction. Therefore, it is essential that selfishness should remain hidden, and therefore be disguised. This is not too difficult because individual selfishness has three spectacular elements: a) I am for myself; b) the world is for me; and c) You are for me too! Marriages, families, and societies in which individual selfishness rules are unsustainable. Perhaps the most important way out is to rebuild societies/cultures from small communities characterized by trust and cooperation. "Reciprocity can be constantly monitored; the members of the community thus ennoble each other in spirit." Therefore, "not only families but also the workplace, church, professional communities, and other civil organizations need to be further developed." ${ }^{37}$ It must be added that

selfishness is not only manifested in the exploitation of our fellow human beings but also leads to the ecological destruction of our Earth. (...) Small communities, exemplary families, and historic churches still play a key role in actively shaping our spiritual environment and bringing more love and the power of a cooperative spirit into our smaller and larger social communities instead of selfishness. ${ }^{38}$ 


\section{Protection of families - protection of society}

From following this train of thought we can conclude that the basis of social existence cannot be individual selfishness but rather social and community solidarity. Here in Europe in the Judeo-Christian cultural circle, this is rooted in one of the greatest biblical commandments, that of neighborly love. However, forced industrialization and urbanization resulting in the huddling of crowds in big cities, also contradicts this. "Our neighbour love has been diluted so much by the mass of our neighbours that are too close that it can no longer be detected at all." ${ }^{39}$ However, the European Union still shares the fundamental principles of "freedom, justice, and solidarity." János Zlinszky wrote about this: "Christianity calls solidarity neighbour love." ${ }^{40}$ The primary field for learning (socializing) love and solidarity is the natural and fundamental component of society and the family. It is therefore in the fundamental interest of the society to protect the family. At the same time, it is at least to the same extent in the interest of the family to protect the solidarity-based (and not selfish) society. If one of them becomes sick, the other too becomes ill. The illness of the family - as we have tried to demonstrate so far-is mostly a kind of "addiction": the integrity and health of the family depends on the nature, integrity, health, and vitality of the social environment around it. Socio-economic dysfunctions are earthquake-like paradigm shifts that induce large-scale changes in the lives and internal relations of couples and families. Stable, harmonious marriages and stable, peaceful families require or would require harmonious, stable, and peaceful social conditions. This has never occurred in the history of mankind, but we must continue to pursue such conditions.

The novelty in the crisis of marriage and the family is its extent and the foreseeable danger of the demographic collapse of society. We also need to measure and develop its defense toolbox, for which we need to know the causes of the major crises. According to my point of view, the main reason for this is the general crisis of values that pervade society. This is ingrained in the internal relations of marriage and the family, which seriously affects the two fundamental (even universal) values: marriage and the family. However, the demographic collapse primarily threatens Europe, which would be the destruction of a large civilization, the "strange death of Europe,', according to the title of Douglas Murray's book. One of the main reasons for this is a kind of "historical fatigue' (Geschichtmüde) that characterizes Europe. Psychologists are diagnosing such a disorder (called "burn out") with increased frequency. Since the Enlightenment, Europe has "produced" a series of ideas that redeem man and society, leading to revolutions and wars. Specifically, the two world wars in the $20^{\text {th }}$ century resulted in enormous devastation and suffering and caused severe disappointment, disillusion, and fatigue. "The more popular the philosophical and political ideas are, the more devastation they leave. (...) The fascist dream, 
like his cousin, communism, wanted to respond to the serious problems of the age, (...) but the devastation left behind them was horrible." ${ }^{\prime 1}$ Both political ideas also destroyed the remaining faith of Europeans, culminating in the launch of secularization. However, "the religion of the continent has provided one of the major-if not most-energies for centuries." ${ }^{\text {42 }}$ With the loss of faith, confidence in fixed values also vanished.

The point is to question everything and never get anywhere; the destruction of ideas is perhaps precisely because we are afraid of where they may lead. (...) If there are any ideas left at all, it is precisely that the ideas represent the problem. (...) If there is still certainty left, it is the doubt about the certainties. ${ }^{43}$

Contemporary psychologists also often face this problem. This is the phenomenon and mental illness of anomie: the hopelessness felt due to the loosening and disintegration of social norms and the lack of new norms, which is no longer a rare state of total hopelessness. ${ }^{44}$ We should not be surprised if this has overtaken the idea of human rights.

The post-war culture of human rights pretends (or their fans pretend) to be a religion itself and, as such, introduces a secularized version of the Christian consciousness. (...) But it is a religion that is never certain of itself, since it does not have safe points. The language is tell-tale. As the language of human rights became more grandiose and more self-deceptive, it became increasingly clear that this system was unable to fulfil its original function. The feeling of such a visible fall and the loss of the safe points is not only disquieting for both the individual and society, but also emotionally exhausting. ${ }^{45}$

Emotional exhaustion, fatigue, anxiety, hopelessness, fear, depression, and panic disorders are all symptoms of anomie and burnout. This is a depressing snapshot of our present and a dark vision for the future. However, even Murray says that there is a ray of hope. "Still, many people are looking for something certain in their lives. Religions, politics, and personal relationships are among the few things that constitute something solid in chaos." ${ }^{46}$ This thought is similar to the hope of a "great reconstruction": "the return to religiosity takes a milder, more decentralized form in which religious faith is not so much an expression of a dogma as a reflection of the community's existing norms and desire for order". ${ }^{47}$ Together with many others,

41 Murray, 2018, pp. 214-216.

42 Murray, 2018, p. 207.

43 Murray, 2018, pp. 221-222.

44 Kopp and Skrabsky, 2020, p. 125.

45 Murray, 2018, p. 211.

46 Murray, 2018, p. 222.

47 Fukuyama, 2000, p. 371. 
I also consider marriage and family to be recurring fixed values and certainty in the lives of pathfinders. In European religions, and even in the values of most of the world religions, marriage and family are sacred things and fixed points. Most of the very close and important personal relationships are related to marriage, family, and kinship, which are part of the capital of trust, a source of happiness. They are worthy of rescue and protection, as well as the soul of Europe since marriage and the family are common treasures of the European community of values. As Robert Schuman wrote, the European Community

cannot remain just a common economic and technical community; it must be given a soul, it must be stimulated by the context of its history, its responsibility for the present and the future, a policy for the human idea. (...) Every European state has been shaped by Christian civilization into what it is. It is precisely this European soul that must be resurrected". ${ }^{48}$ Is this still possible? Yes, if - in agreement with ecophilophist László Ervin—we realize that “our future was there in our past, we just didn’t notice it and went past it."

It is true that our daily reality is not the same as our tomorrow imagined today. Many of our values have been lost and many of our ideals have not become a reality. However, we still have values that can be salvaged from our rich heritage, such as those related to marriage and the family. We can change the world and we can save our values if we change ourselves.

If we want to be part of the huge flood that is lifting humanity out of crisis and is driving it towards a positive future, we need to change ourselves. Everything else follows from this. There will be no need to tell us how to think and what to do: we will realize this ourselves. We become more mature and better individuals. ${ }^{49}$

\section{Crises of values and definitions}

If we transcribe core values into law, our aim is to become permanent and follow the norms. As a result of this, values become legal concepts. Legal concepts must be defined and their exact and correct content and meaning determined. For this, the concepts need to be analyzed and interpreted. This is performed by complementing and helping each other and by jurisprudence and law enforcement. There are well-known types of legal interpretation: grammatical, logical, historical, taxonomic, and correctness. The latter is aimed at exploring the correct content, i.e., the 
value content of law, and at comparing the legislation with the basic principles of law (most recently with human rights and constitutional fundamental rights) and reconciling them with their value content. The more general or abstract the law is, the more correct or deemed to be correct interpretation can be read from a given legal concept. The situation is aggravated by selfish individualism, which favors individual value priorities (there are as many types of interpretation as there are people) and, in conjunction with it, general value relativism, which overexpands and disperses the original content of legal concepts as core values with reference to the freedom of more and more interpretations. I would like to briefly illustrate this with the concepts of marriage, maternity, and family.

The origin of marriage goes back to the obscure prehistoric times, and it can be assumed that there had already been a shift from promiscuity to monogamous relationships in primitive societies (small communities) for the sake of genetic integrity and health of offspring. This was reinforced by the agricultural revolution and the development of private property, as we have already seen. The role of husband and father, the inheritance of genes, and personal ownership of property have been overestimated, and, at the same time, the roles of wife, mother, and woman have been re-evaluated to the detriment of the female sex. However, feminist movements for the liberation of women were organized only after the Industrial Revolution, which was completed in the second half of the $20^{\text {th }}$ century. Whether women have achieved their most important goals and the justification for their militancy nowadays has already been highly debated. However, women and men are now partners and not opponents or enemies. Due to the concentration, centralization, subsequent socialization and nationalization, and finally multinational and transnational privatization and globalization of capital, the family economy as the basis of the private economy almost disappeared, its importance and proportion decreased significantly, the basis of the existence of patriarchate ceased, and the family became a group of wage workers and a consumer community. In the "two wage earners" family model, it is an obsolescent question to ask, "Who is the master at the house?" However, this does not mean that the rivalry ends, but rather the match is "doubtful." In the case of large masses, the weight of inheritance has also decreased and the genetic identity of the descendants is not as important as it once was (e.g., in "mosaic families"). In proportion to this, the strength of the monogamous marriage bond also decreased. This can be illustrated by the well-known public opinion that marriage is "just a paper"; it is not needed, the essence is the emotional community and de facto coexistence. At the same time, paradoxically, the looser, non-committed, alternative forms of relationship that rival marriage almost invariably claim the status and legal effects of marriage, especially its benefits (rights). Is it a crisis, or is it the developmental phase of the evolutionary process of marriage as a legal institution that was reached in the 21st century? We will return to this question. The situation is similar to the legal concept and the legal institution of maternity. Pregnancy and maternity are a long-recognized and valued status and legal state with associated benefits. At the same time, the principle of "there is only one mother whose identity is certain' is 
no longer the same: we can speak about even five or six mothers, partly due to frequent (multiple) divorces and remarriages, and partly due to the increasing number of human reproductive procedures. At the same time, paradoxically, an increasing proportion of women (wives, unmarried partners) are unable (for biological reasons) or consciously do not want (for mental or rational reasons) to have children. The social and legal value of maternity has declined. One of the most important reasons for this are the slogans of feminist movements interpreting maternity as an extension of women's inequality, such as "a woman is not a domestic worker," "a woman is not a slave to her own child," "a woman is not a breeding animal," "a woman is not a parent machine," etc.

The very commendable effort to create equality for a woman subject to man has led European civilization to an evolutionary impasse, and its biological foundations are destroyed at an accelerating pace. (...) The main reason for the demographic collapse is the change in the role of women and the relegation of the role of maternity to the background, which has been moving towards total rejection for an increasing number of women in the recent decades". ${ }^{50}$ According to the professor, it was a mistake to interpret emancipation as equality in all areas of life, and to raise the biologically established role of women and the consequent natural difference from men as a social problem. ${ }^{51}$

This suicidal strategy, which seems to win here, loses in the long run. ${ }^{52}$ The described impairment (devaluation) of marriage and maternity naturally have a serious influence on the concept and institution of the family as well. As we have seen, industrialization-either capitalist or socialist-destroyed the multi-generational large family while social mobility loosened marriage and reduced the willingness to have children. We have shifted from the nuclear family model (a married couple with one child) to the single-parent family model and even to personal career-building singleness, which is again only a manifestation of selfish individualism. A sign of the devaluation of marriage and family is the incongruence, i.e. the divergence of marital status and actual life situation (e.g., despite being married on paper, the parties actually live separately and even have a new partner and a child originating from him/ her), which has become increasingly common in the last half century. Successive "polygamy' is also a kind of promiscuity, almost as if we had returned to prehistoric communities. What the future holds remains unclear. Will there be an "evolutionary regression" or will we reach a kind of dead end from which we recognize the need to retreat? How this will be experienced by future generations, children whose utmost interest would be a harmonious and stable marriage of their parents and a family community that provides security. 


\section{The toolkit of the protection of marriage and the family}

If the causes of the crisis of marriage and family are extremely diverse and different, it is clear that the tools for their protection can only be the same. It is the primary task and duty of the current policy to select the most appropriate instruments for each crisis symptom. A comprehensive social policy program, in particular the population policy program and family and child protection, should be prioritized as key issues in the election programs of all political parties. Economic policy, social policy, taxation, and budget policy, and even individual policies (education and health policies) must be adjusted to support these goals. Quality programming requires a scientific basis. To achieve this end, research in individual disciplines, including disciplines more closely related to marriage and the family (e.g., statistics and demography, family sociology, relationship psychology, household economics, pediatrics, pedagogy, etc.) must be coordinated and its research results integrated and embedded in social programs. The implementation of the programs requires specific objectives that must be ranked, financed, managed, and monitored. It is good if this is done within the administrative sphere by a strongly professional and versatile educated apparatus with complex experiential knowledge. This should also serve as a political decision-making tool and guidance for future legislation. Family protection objectives and specific programs need to be translated into law, more specifically into the relevant branches of law within the legal system, in order to create a coordinated, uncontroversial subsystem of family protection law. This also requires a high degree of complexity and the ability to think in a broad context from the "family protection lawyers," which induces (continuous) training in this direction. However, the effectiveness of the best professional bureaucracy is also undermined by tracking patterns of behavior in the opposite direction, especially in relationships between parents and children, friends, and co-workers. For example, children of divorced parents are more likely to get divorced themselves than those whose parents have lived their lives together in honesty and fidelity, simply because such children "get used" to divorce, and "regard the divorce of their parent as natural." 53 People have to be raised to recognize and understand the benefits of marriage, starting a family (having children), maternity and paternity, and family life. The best terrain for this "socialization" process is the family with mother, father, and grandparents as role models illustrating positive patterns of behavior that can be followed. The principles of education and core values (patience, peace, forgiveness, fidelity, mutual support, and selfless love) preserve the lives of families as well as the personality and humanity of the family members and society as a whole in an orderly channel, provided that modern information and communication tools do not exert a destructive effect in the opposite direction (which has unfortunately numerous examples, especially in the programs of commercial television and in the virtual world of the Internet). We are still searching for or trying to develop the civil and state means to 
protect marriage, family, and children against such negative influences. It will not be easy; there is a high prevalence of destroyers nowadays in many forms, including those who are fighting with the weapon of human rights, insidiously reversing their meaning and purpose.

\section{The legal dilemmas of the protection of marriage and the family}

My dear professor, Imre Sárándi, always began his family law lectures with the pessimistic sentence: "Where family law begins, family ends!' This sentence has double meaning. On the one hand, he pointed out that court statistics show that nearly half of civil lawsuits are family lawsuits, divorce proceedings, and their ancillary lawsuits, i.e., proceedings in connection with spousal maintenance, child support, right of tenancy of the common house, distribution of community property, placement of the child, visitation rights, etc. These signify the end of marriage and family and settle and close conflicts around divorce. On the other hand, the sentence also suggests that we do not need law in the pre-divorce phases, i.e., in betrothal, in contracting marriage, in matters of internal content of marriage, and in the intimate sphere of the family. (Humorously, in marriage and the family, the law is like an elephant in a China shop; it's better not to let it in!) The relations between spouses and family members belong to a kind of "private sphere without law," an area of private autonomy where there is only a little room for general social norms, where almost exclusively the will or agreement of the parties is the governing norm. This means that the parties, spouses, and family members can shape their relationships independently of each other. Therefore, many representatives of the legal literature and the legislation considered that the law of marriage should contain only the formal, procedural, registrational rules, validity conditions, and grounds for invalidity, which are the most important for society, while only the dissolution of marriage and its related issues require more detailed regulation due to the further fate of the common children and the common property. There are at least two important reasons for this. First, marital and family relationships have been freed from the "bondage of private property"; from the male and father (ownership) power of the bonus et diligens pater familias inherited from Roman law" Second, compared to strictly moral ecclesiastical law, state regulation regarded marriage as a contract in which the parties are equal and subordinate, free to shape the content of their personal and property relations on the basis of dispositive regulation. However, traditions have a very strong power; male and paternal power is deeply ingrained in European and individual national cultures; e.g., in Hungary, many wives still call their husbands "my lord.". The law did not have a sufficient response to the case where the pater familias was neither a bonus (benevolent) nor 
diligent (careful). Domestic violence, violence against children, or the squandering of family property are not new phenomena. The emancipation movements and later the defenders of children's rights justly and rightly demanded more detailed legal regulations and later law enforcement. Women's rights, especially maternal rights and children's rights, have been occupied prominent place in international human rights instruments, national constitutions, and at the level of national legislation. With regard to the nature of the norms, there are imperative orders, in particular prohibitive norms (criminal offenses and misdemeanors); mandatory norms, from which the parties cannot deviate even with equal will (only for the benefit of the woman or children, e.g., in labor law or in child support and placement questions); and dispositive rules that can be set aside by the parties and replaced by a consensus between them (e.g., matrimonial property matters). Among rules relating to family support, recommendatory and indirect incentive norms as the legal conditions for benefits are common. The application of norms imposing obligations and their enforcement by public authorities is a particularly sensitive issue nowadays. According to the common saying, one cannot love someone or demand loyalty by order, but their absence can be imputable to the breaker of the norm and can be sanctioned. The same is true of the obligation of mutual support between spouses: it cannot be enforced, but its failure can be sanctioned. The situation is different with regard to the responsibilities of the parents and the rights of the children, where the regulation is much more detailed and the sanctions more differentiated. A separate area of legal dilemmas is the tolerance, recognition, and support, or, conversely, the prohibition or sanctioning of atypical marriages, alternative forms of cohabitation, and family compared to good (according to the legal terminology: typical, ideal) marriages. How long should the state and law in this area be value-neutral or indifferent, and where is the limit of deviance? Where is there a possibility of positive discrimination and, on the other hand, where does state intervention and legal regulation contravene the prohibition of discrimination? The first and most difficult issue is the legal definition of marriage and family and the narrowing or extension of these notions. A separate dilemma is to whether to connect the two concepts or to interpret and treat them separately. When is the too narrow definition discriminatory against people living in excluded life relations, and when does the too broad definition itself means an impetus towards alternative and atypical life relationships, and when does it further destroy typical and traditional relationships and family life? Do changes in social customs or the will and values of the legislature (majority, politics) shape (and create) law and, which is motivated by which? These are difficult legal dilemmas and questions that must be answered. 


\section{The perspective of marriage and the family}

According to the most pessimistic predictions, marriage and the family - at least in Western civilization - have no future. This is clearly an unacceptable perspective. If the family is invariably the natural and fundamental constituent (unity, cell) of society and it has no future, then the whole of society does not have a future either, since if the constituent elements of something disintegrate, the whole system collapses. This is true even if we call the disintegrating society an "open society." Similarly, an "open marriage" is not in fact a marriage, it is a specific contract, a consensus of at most two (or more involved) persons relating to their personal relations and the settlement of their cohabitation. According to the other overly optimistic prediction, we can expect the renewal, renaissance, and prosperity of marriage and family because people will only now be freed from the previous oppressive religious moral and civic property interest pressures and burdens. The truth on this question falls somewhere between the two extreme positions, and the question of which pole the balance tongue tilts toward depends on what and how successful the solutions we find are in dealing with the crisis. Legal instruments alone are insufficient tools for success. It is also necessary to rehabilitate and respect natural laws, as well as to renew and protect moral values. Significant material coverage is required to expand and apply the family protection toolkit. If it is successful, we also need social recognition and unanimous support. This is also the case in Hungary; Hungarian people are the most family oriented in Europe. ${ }^{54}$ Children already need to be socialized for marriage and starting a family, for maternity and paternity, and its most effective means are good examples of a harmonious marriage. i.e., a family that creates peace and security in which children can thrive. As man is not only a rational but also a moral and even spiritual creature. Marriage is more than just an agreement based on a reasonable balance of interests: it is a moral and spiritual alliance. That is the new worldwide attempt of covenant marriage (or "marriage alliance"), which is about the lifelong commitment of the parties. It is nothing more than a moral and spiritual reinforcement, an appreciation of the legal concept of marriage and family. This is reflected in the solemn framework of marriage, which emphasizes not only the public law and social significance but also the transition from individual to federal (cohabitation) status, which brings about the unity of a "couple of people." Just as each person is sole, single, and unrepeatable, so too the commitment between two people creates an alliance that is also singular and unique. Spouses are complementary to each other; this community cannot be owned and people can only become a part of it. ${ }^{55}$ Such marriage and family have a physical and mental "health-protecting" function and impact for both children and their parents. 
In the relationship between two people and then between parents and children, the essence of marriage and family is life commitment, unconditional trust, and devotion. Whoever is able to have such a relationship has at least embarked on the path that leads to self-fulfilment, self-realization, and a positive quality of life. (...) The role of family and marriage has never been as important as in modern society from the point of view of the quality of life, balance, and tolerable social atmosphere of the individual and of the next generation. ${ }^{56}$

Law-family law and constitutional law-cannot be without an image of humans and society as a goal and value. Within the law, special emphasis is placed on the image of the marriage and family model and the need for institutional protection. The original meaning and content of concepts and institutions must be restored and preserved. Only treatment and protection as a priority, in accordance with social perception, will give the institution of marriage and family a new rank and perspective. There is room for "competition" between legal systems only in terms of a sustainable image of human and society and a sustainable and maintainable model of marriage and family, and not in connection with their destruction. The same applies to the oversupply of extramarital partnerships (also called alternatives to marriage), and their competition with each other and with marriage. We cannot, for example, demand the same or even more rights for both heterosexual and same-sex partners than spouses with less commitment and responsibility and with a looser and more disruptive set of values.

Marriage and family are natural and universal institutions that already existed before the law and would probably exist without it. However, it is no coincidence that both have become part of the law and a fundamental legal value. Law, as a powerful normative tool, is capable of protecting and supporting the institutions of marriage and family, which, like law itself, is for man. Therefore, we have to watch out for marriage and family as much as possible, and, if needed, even beyond our strength. After all, if we manage to save marriage and the family, we will save man, humanity, and "human" society. In order to achieve this, we have natural and moral laws coupled with human rights and constitutional foundations. The rest depends on us. 


\section{Bibliography}

BIвÓ, I. (1986) Az európai társadalomfejlődés értelme. Selected studies, Vol. III, Budapest: Magvető Könyvkiadó, pp. 5-123.

CSEH-SZOMBATHY, L (2000) ‘Állandóság és biztonság a családban', Vigilia, 65(8), pp. 587-590.

ENGELS, F (1977) A család, a magántulajdon és az állam eredete. Selected works of Marx and Engels, Vol. III, Budapest: Kossuth Kiadó, pp. 457-556.

Freund, T. (2004) 'Az önzés és az elmagányosodott ember', Magyar Szemle, 14(3-4), pp. 113-131.

Fromm, E. (1994) Birtokolni vagy létezni? Budapest: Akadémiai Kiadó.

FukuYAmA, F. (2000) A Nagy Szétbomlás. Budapest: Európa Könyvkiadó.

GALLAI, S (2019) ‘A családpolitika helye a demográfiai válsággal küzdő Európában’ in: Európai családpolitikai kitekintő. Budapest: KINCS Kiadvány, pp. 15-28.

GERGELY-BAKA, I. (2021) 'A magyarok a legcsaládcentrikusabbak Európában', Képmás, 2021/3, pp. 44-45.

HARARI, Y. N. (2016) Homo Deus. Budapest: Animus Kiadó.

HARARI, Y. N. (2020) Sapiens. Budapest: Animus Kiadó.

KOPP, M. AND SKRABSKI, Á. (2020) A boldogságkeresés útjai és útvesztői. Budapest: L’Harmattan Kiadó.

KovÁcs, J. (2007) Bioetikai kérdések. Budapest: Medicina Kiadó.

LÁszLó, E. (2002) Meg tudod változtatni a világot. Budapest: Magyar Könyvklub.

LORENZ, K. (1988) A civilizált emberiség nyolc halálos büne. Sopron: IKVA Kiadó.

LEJeune, R. (2015) Politika és életszentség. Budapest: Máltai Könyvek.

MARX, K. AND ENGELS, F. (1965) A kommunista kiáltvány. Budapest: Kossuth Kiadó.

MiCHEL, K. AND VAN SCHAIK, C. (2019) Az ember három természete. Budapest: Typotex Kiadó. MurRAY, D. (2018) Európa furcsa halála. Budapest: Alexandra Kiadó.

POKOL, B. (2010) Európa végnapjai. Budapest: Kairosz Kiadó.

POKOL, B. (2015) 'A jogtudomány társadalomtudományosodása (és így perspektivikus létrejötte)', Jogelméleti Szemle, 2015/2, pp. 106-130.

Rerum Novarum. Encyclical of Pope Leo XIII on the situation of workers.

SCHUMACHER, E. (1991) A kicsi szép. Budapest: Közgazdasági és Jogi Könyvkiadó.

SzLAdITS, K. (ed.) (1941) Magyar Magánjog Vol. I., Budapest: Grill Kiadó.

ZlinsZKY, J. (2007) Közéleti és jogászi etika. Budapest: Szent István Társulat. 